\title{
TANITMA: Evangelia BALTA, Gerçi Rum İsek de Rumca Bilmez Türkçe Söyleriz Karamanlılar ve Karamanlea Edebiyat Üzerine Araşttrmalar, Türkiye İş Bankası Kültür Yayınları, İstanbul, 2018 (3. Basım), $406 \mathrm{s.}$
}

Salih İNCí1

\author{
Gerçi Rum isek de Rumca bilmez Türkçe söyleriz, \\ Ne Türkçe yazar okuruz ne de Rumca söyleriz, \\ Öyle bir mahludî hatt-ı tarikatımız vardır, \\ Hurufumuz Yunanice, Türkçe meram eyleriz.
}

Kitap adını, yukarıdaki 1896'da yayınlanmış şiirin ilk mısrasında geçen ifadelerden almakta ve bu topluluğun dili olan Karamanlıca'yı en güzel şekilde özetlemektedir. Kitabın yazarı Evangelia Balta, 1955 Kavala doğumlu Karamanlı mubâdil bir ailenin çocuğudur. Doktora eğitimini Sorbonne Üniversitesi’nde alan yazar, çalışmalarını Osmanlı Tarihi, Karamanlılar ve Karamanlıca üzerine yoğunlaştırmış, uzun süre Atina'daki Küçük Asya Araştırmaları Merkezi’nde (KAAM) çalışmış, Yunan Ulusal Araştırma Vakfı Tarih Araştırmaları Enstitüsü müdürlüğünü yapmış, 2013’te Türk Tarih Kurumu şeref üyesi seçilmiş ve 2014’te de Osmanlı Tarihi çalışmalarına yaptı̆̆ı katkılar nedeniyle Cumhurbaşkanlığı Liyakat Nişanına layık görülmüştür. Kitap yazarın değişik zamanlarda Karamanhlar ve Karamanlıca adına farklı dillerde kaleme aldığı makale ve verdiği konferansların bir araya getirilmesiyle oluşmuştur. Bu nedenle kitapta İngilizce, Fransızca ve Yunancadan oluşan makalelerin Türkçeye çevrilmesinde 11 kişilik kalabalık bir ekibin emeği söz konusudur.

Kitabın içeriğinin tanıtımına geçmeden önce Karamanlıların (Karamanlides) kimler olduğundan kısaca bahsetmek gerek. Bu grubun etnik aidiyeti meselesini, yazar ileriki sayfalarda kısaca ele almıştır. Ancak konunun anlaşılması için meseleye dair söylenenleri ilk başlarda hatırlatmakta fayda vardır. Her ne kadar kitabın başında geçen "Gerçi Rum isek de" ifadesiyle bunların Rum (bu günkü Yunanistan'daki Ortodoks Hristiyanlarla aynı etnik kökenden geldikleri anlayışı) oldukları savını peşinen destekliyormuş gibi görünse de, konu tartışmalıdır. Ayrıca Osmanlıda bu kelime sadece bir etnik topluluğu değil, aynı mezhebe bağlı (diyofizit = İsa'da iki tabiatın varlığına inanan) bütün Ortodoksları ifade etmekteydi. Karamanlıların ana dili Türkçe (bu dil yazıya Yunan alfabesiyle aktarılmaktadır), dini ise, İstanbul'daki Patrikhane'ye, Rum Ortodoks Kilisesine tabi Hristiyanlıktı.

Yazar Karamanlıların kimliğiyle ilgili iki görüşün olduğunu söyler. İlk görüşe göre bunlar, batıdaki dindaşlarından uzak kaldıkları için Türkçe konuşmak zorunda kalan Yunan / Helen kökenlidirler, ikinci görüşe göre ise Bizans'ta paralı asker olarak kalan, ancak dillerini korurken dinlerini değiştiren Türk kökenli bir topluluktur. Eğer bir çeviri hatası değilse bu etnisite ve tanımlama sorunu yazarın kalemine de yansımış görünmektedir. Zira yazar bu gruptan genellikle "Türkçe konuşan Ortodokslar" (s.103-105) diye bahsederken, bir yerde "Anadolulu Türk Ortodokslar" (s.104), başka bir yerde de "Anadolulu Türkofon (Türkçe konuşan) Ortodoks Topluluğu” (s.103) tabirini kullanmaktadır. Yazar, her ne kadar bu toplumun Karamanlılar olarak anıldığını söylese de, yaşadıkları yerlerin Niğde, Kayseri, Karaman ve civarları dahil olmak üzere Anadolu'nun Güneyinden Kuzeyine kadar uzanan geniş bir hattaki bölgeyi kapsadığını söyler (s.103).

Doç. Dr., Kırklareli Üniversitesi, İlahniyat Fakültesi, Felsefe ve Din Bilimleri Bölümü (Kırklareli, Türkiye), incisalih@klu.edu.tr, ORCID ID: 00oo-0003-2252-5564 [Makale kayıt tarihi: 07.11.2019-kabul tarihi: 20.12.2019; DOI: 10.29000/rumelide.657965] 
Kitabın içindekiler kısmının, numaralandırılarak bölüm ve alt bölümlere ayrılarak verilmemiş olması bir eksiklik, bu ayrımı ancak kitabı okuyunca fark edebiliyorsunuz. Kitap, yazarın sunuş ve girişinin ardından, konu başlıklarına uygun olarak yerleştirilmiş çeşitli makalelerin oluşturduğu 3 ana bölümden müteşekkil. Sonunda ise başta Osmanlı Arşivi, Küçük Asya Araştırmaları Merkezi Arşivi olmak üzere çoğunluğu Yunanca ve Karamanlıca olmak üzere birincil ve ikincil kaynaklardan oluşan çeşitli dillerde geniş bir Kaynakça ve yine kapsamlı bir dizin yer almaktadır. Yazarın sunuş kısmında da ifade ettiği gibi bu makaleler değişik zamanlarda yazıldığı için, kitap haline getirilince doğal olarak bazı tekrarlara düşülmüştür. Yazar makale bütünlüklerinin bozulmaması için bunları olduğu gibi koruduğunu ifade etmiştir. Türk akademik camiasında yeteri kadar çalışılmamış bu kitabın alana çok değerli katkılar sağlayacağı muhakkaktır.

Yazar önsözde son 10 yılda konuya dair yapılan akademik çalışmaların artmasının sevindirici olduğunu, zira yakın zamana kadar bu konuda sadece Ortodoks din adamlarının, aydınların ve Protestan misyonerlerin yazdıklarıyla yetinildiğini ifade ederek yeni çalışmaların hem Yunanistan hem de çağdaş Osmanlı milletlerinin edebi külliyatlarına katkı sağlayacağını ifade etmektedir. Burada yazarın kullandığı çağdaş Osmanl milletleri tanımı (s xı), belki de bu döneme dair ön yargılı bakışlara karşı alternatif bir tanımlama olarak okunabilir.

Kitaptaki malzemelerin bir kısmı Osmanlı Arşivlerine, çok büyük bir kısmı ise Atina'daki Küçük Asya Araştırmaları Merkezi Arşivi'ndeki (KAAM) kilise, cemaat ve okul defterleriyle, çoğu KAAM’a devredilen kişisel arşivlerden (anılar, tapular, kitaplar vb) oluşmuştur. Burada KAAM’a ayrı bir parantez açmak lazım. Bilindiği üzere 1923 Lozan Barış Antlaşması'na ek olarak yapılan sözleşmeyle Türkiye-Yunanistan arasında (zorunlu) karşılıklı nüfus değişimi (Nüfus Mübâdelesi) anlaşması yapılmıştır. Buna göre Batı Trakya'dakiler hariç tüm Yunanistan'daki Müslüman Türkler Anadolu'ya (takribi 500 bin), İstanbul'dakiler hariç Anadolu'daki tüm Hristiyan Ortodokslar da Yunanistan'a (1 milyon 200 bin civarı) gönderilmiştir. Bu değişimde (mübadele) vatandaş kavramı din esası üzerine temellendirildiği için, kendileri Türkçe konuşan ve hatta kimileri de Türk olduklarını söyleyen ve tek kelime dahi Yunanca bilmeyen Ortodoks Türkler de Hristiyan oldukları için, Yunanistan'a gönderilmişlerdir. İşte bu zorunlu göçe tabi olanlar içinde Karaman, Niğde, Aksaray, Göreme vb yerlerde yaşayan Karamanlılar da vardır. Anlaşma gereği mübadillere yanlarında tabu, kayıt defterleri, taşınabilir değerli malları, kutsal eşyaları vb taşıma hakkı verilmiştir. İşte yukarıda bahsettiğimiz KAAM, Karamanlılar da dahil bu mübadillerle ilgili tüm resmi, gayri resmi ve daha sonra anı ve hatıralarla oluşturulacak olan sözlü anlatımları da yazıya geçirerek çok büyük bir yazılı sözlü arşiv oluşturmuştur. Başlangıçta Fransız Melpo Merlier’in yönettiği 1930'larda sırf bu amaçla kurulan kurum, bu güne kadar oluşturduğu bu büyük birikimiyle Anadolu'dan gelen mübadillerin (Küçük Asya Rumlarının) hafızası konumundadır. (Türkçe WEB adresi : http://tr.kms.org.gr/).

Yazar çalışmanın sunuş kısmını, bu eserini kendisine ithaf ettiği ve Türkiye'deki Karamanlıca çalışmaların başlatıcısı olarak gördüğü Robert Anhegger (1911-2001) hakkında bilgi vererek sonuçlandırır. Anhegger, Evangelinos Misailidis'in Karamanlıca olarak 1871'de İstanbul'da basılan 4 ciltlik Temaşa-i Dünya ve Cefekâr-ü Cefakeş romanını Seyreyle Dünyayı adıyla günümüz Türkçe harfleriyle (Vedat Günyol'la birlikte) yayınlayan bir isimdir. (Cem Yay., İst. 1986). Zamanla Yunanistan ve Türkiye'de Karamanlıca üzerine yapılan çalışmalarla belli bir birikim oluşmuş ve bunlar yazarın da büyük gayretleriyle sempozyumlara dönüşmüştür. Bunların ilki 2010'da Kıbrıs'ta Birinci Uluslararası Karamanhca Çalışmaları Konferansı adıyla yapılmıştır. Üçüncüsü de 2 Kasım 2013 tarihinde Türkiye'de Kapadokya'da yapılmıştır. 
Kitabın giriş kısmı, “Karamanlıca Kitapların Çığlıklarıyla Fısıltıları” başlığıyla yer alır. Yazar uzun bir geçmişi (ilk eser 1718) olan Karamanlıca edebiyat basımının, mübadeleden sonraki ilk on yılda Yunanistan'daki mübadillerin birkaç basit yayını, iki dilli ama kısa ömürlü olan Muhacir Sedası adlı gazete ve oy toplamak için gelen Yunanlı siyasetçilerin "muhacir dili”nde bastırdıkları broşürler dahil bütün her şeyin 1935'de sona erdiğini söyler. Kendisi gibi mubadil çocukların evlerinde dede ve babalarının konuştukları bu dili anlamadıkları ve bu dilin nasıl küçümsendiğine dair hatıralarını anlatır. (s.1-5). Giriş bölümünün ekinde ise KAAM’ın görevlendirdiği bir araştırmacı olan ve bu konuda ilklerden sayılan Eugène Dalleggio'nun 1956'larda Karamanlıca malzeme toplamak ve birebir görüşmeler yaparak sözlü anlatımları yazıya dökmek için mübadeleyle Karaman civarından gelip Yunanistan'daki Evia (Eğriboz) Adası ve civarına yerleşen kişilerin köylerine yaptığı gezileri ve topladığı malzemeleri anlatır. Onun bu ve benzer faaliyetleri, Karamanlıca literatüre dair bibliyografyanın oluşmasına ilk kaynaklık eden çalışmalar olarak bilinir. (s.13-29)

\section{Anadolulu Ortodoksların Tarihine Bakışlar}

Eserin ilk bölümü, “Anadolulu Ortodoksların Tarihine Bakışlar” adını taşıyor ve üç makaleden oluşuyor. İlki, "Küçük Asya Araştırmaları Merkezi’ndeki Karamanlıca ve Türkçe Sicil Defterlerinin İçerikleri”, adlı makale. Mübadele sırasında Mübadillerin değerli eşyalarıyla beraber bazı resmi ve özel evraklar Kamu Yararı ve Mal Mübadelesi Sandığı adlı resmi bir kuruma teslim edilmiş, bunların bir kısmı dönüşte mübadillerin kendilerine ve cemaatlerin mülkiyetine iade edilmiş kalanlar ise Yunan Devlet Arşivlerine ve Milli Kütüphaneye aktarılmıştır. Bunun yanı sıra hatırı sayılır bir malzeme de, gerek bağış, gerek satın alma vb şekillerde KAAM tarafından toplanmıştır. Yazar bu makalede burada bulunan malzemeler hakkında detaylı bilgiler vermektedir. En erkeni 1807 yılına ait olan çevre köylere ait defterler içinde vergiler, nüfus sayımı, satış akitleri, alacak verecek senetleri, idari, adli, dini görevlendirmeler, evlilik, miras konuları, vaftiz kayıtları, kilise, okul görevlileri ve giderleri vb yer almaktadır. Bunlar içinde Kayseri, Gelveri, Nevşehir, Ürgüp gibi yerlere ait defterler de bulunmaktadır. Bunlardan mesela Vekse Köyü’ne (Özlüce) ait bir defterde yer alan bilgilerden, köyün Kilise kasasının Kayseri'ye askerlik muayenesi için gideceklerin yol parasını ödediğini, yine 1923 nüfus sayımı için gelen Osmanlı memurlarının masraflarının da buradan ödendiğini öğreniyoruz. Yine bu kasa defterinde Papa Eftim'e yapılan maddi desteklerin de kayıt altına alındığını öğreniyoruz. (s. 43)

Bu arada dipnotta verilen bilgide yazar Evangelia Balta'nın mübadele öncesinde bölgedeki Hristiyanları Türk Ortodoks Kilisesi'ne katılmaya çağıran 36 sayfalık, "Papa Eftim Efendi’nin Ortodoks ahaliye çağrısı ve İstanbul Patrikhanesi’ne karşı savunma” adlı Karamanlıca bir metnin olduğunu görüyoruz. (s. 43, dipnot 16). Burada bu bölgeden ve topluluğun içinden çıkan bir hareket olduğu için kısaca Papa Eftim olayını hatırlamak gerekir. Birinci Cihan Harbi’nden Osmanlı İmparatorluğunun mağlup çıkmasıyla Ortodoksların İstanbul'daki temsilcisi olan Patrikhane, yayınladığı bir beyanname ile artık Osmanlıyı tanımadığın ilan etmiş ve galiplerin yanında saf tutmuştur. İşgalcilere karşı Patrikhanenin tavrını onaylamayan ve kendisini "Türk" olarak tanıtan Keskin Piskoposu Papa Eftim, Patrikhane'den ayrılıp 1922'de Kayseri'de bağımsız Türk Ortodoks Kilisesini kurunca, o günün şartlarında sayıları belli olmayan ama küçük olduğu sanılan bir grupla Patrikhaneden ayrılmıştır. Bir dönem Patrikhaneyi uzun bir süre uğraştıran Papa Eftim olayı umumiyetle Türk tarih yazımında ön plana çıkartılırken, olay aynı oranda Patrikhane ve Yunan yazımında görmezlikten gelinmektedir, nitekim benzer bir tavrı kısmen de olsa bu kitapta da gözlemlemekteyiz. Yazarın kendisi tarihte yaşanmış olayların aktarımının, yani tarih yazımının çoğunlukla olayları, siyasi ve ideolojik nedenlerden dolayı olduğu gibi aktarmadığını (s.100 vd) söylemektedir. Yazar Yunanlıların Anadolu'ya çıktıklarında Patrikhanenin Venizelosçulara taraf olmasının, bu kurumun itibarını yıprattı̆̆ını söylemekle yetinmektedir. (124) Burada yazarın 
Patrikhaneye karşı çok özenli bir dil kullanmasını aralarındaki bir kutsal bir bağ nedeniyle belki anlayabiliriz. Ancak Patrikhanenin bu dönemdeki yanlış tercihinin, bu topraklarda mübadele örneğinde olduğu gibi büyük felaketlerin yaşanmasına neden olan asıl sebeplerden biri olduğunu da hatırlamak gerekir.

Yine bu defterlerden Tavlos karyesinde, çok ilginç anılardan bahsedildiğini görüyoruz. Anı sahibi döneminde yaşanan tuhaf şeyleri gün ve tarih olarak detaylıca yazmıştır. Örneğin 1834'de çok erken ya da çok aşırı yağan, karlı günleri, aşırı kıtlık günleri ve un fiyatlarını, 1835 ve 1836 yıllarında artçılarla beraber yaşanan onlarca depremi ve tahribatları kayda geçirmiştir (s. 61-62). Makalenin sonundaki ekte ise Silata (Zile) Sicil Defterinden alınan "Gelecek Nesillerin Dikkatine Yazılmış Tarihçe" adıyla bir mübadil’in uzun hatırlarına yer verilmiştir. (. 63-72)

Bölümün ikinci makalesi olan "Mübadillerin Dilinden Bir Destan ve Anılar" adlı çalışmada, bugünkü Güzelyurt, eski adıyla Karvali / Gelveri kökenli olup bu gün Kavala yakınlarındaki Nea Karvali'de (Yeni Karvali) yaşayan göçmenlerin göç hikâyeleri; anılar, şarkı ve şiirlerle anlatılmaktadır. Ortak konu; memleketten ayrılık, yollarda çekilen sıkıntılar, hastalıklar, salgınlar, Yunanistan'da yaşanan olumsuzluklar ve bitmeyen hasret. Makale ekinde yer alan Karvalili Kosma Çekmezoğlu'nun 1925-1930 yıllarında Karamanlıca olarak yayınladığı 72 dörtlükten oluşan Göç Destanı adlı şiir, acıklı göç hikâyelerinin yanı sıra, o dönem bu topluluğun dili, edebiyatı, dini, sosyal yaşantıları hakkında oldukça önemli bilgiler vermektedir. (s. 73-86). Burada bu destan üzerinden Karamanlıca olarak bilinen ve Yunan alfabesiyle Türkçe yazılan dile dair tablo halinde bir iki örnek vermek istiyoruz:

\begin{tabular}{|c|c|c|c|}
\hline YUNANCA & OKUNUŞU & KARAMANLICA & TÜRKÇESİ \\
\hline$\Theta \varepsilon o \varsigma$ & Theos & A $A \lambda \lambda \alpha x$ & Allah \\
\hline К & Konstantinupolis & $\Sigma \tau \alpha \mu \pi о \lambda$ & Stampol (İstanbul) \\
\hline Xं́pa & Hora & Карүıє & Karye (Köy) \\
\hline EOvos & Ethnos & $\mathrm{M} \backslash \lambda \lambda \varepsilon \tau$ & Millet \\
\hline Ayios & Ayios & $A \zeta \measuredangle \zeta$ & Aziz \\
\hline$\theta \dot{\alpha} \lambda \alpha \sigma \sigma \alpha \alpha$ & Thalassa & $\delta \varepsilon v i \zeta$ & Deniz \\
\hline
\end{tabular}

Yazar birçok yazılı belgelerin içinden niçin yukarıda bahsettiğimiz anı, şiir gibi sözlü ürünleri kullandığını açıklarken, tarihte yaşanmış olayların aktarımının, yani tarih yazımının çoğunlukla olayları, siyasi ve ideolojik nedenlerden dolayı olduğu gibi aktarmadığını, dolayısıyla bir şiirde, ya da yaşanmış hatıratlarda anlatılan hissiyatın hiçbir belgede bu şekilde ifade edilemeyeceğini söyleyerek tarih araştırmalarında yeni bir olguya, "sözlü tarih"e işaret etmek istediğini söyler. Sözel malzemelere doğal olarak kuşkulu yaklaşımların olmasını da haklı bulan yazar, bu sözlü geleneğin de ancak tarihsel analizlerden geçirilerek kullanılması gerektiğini not eder. (s. 100-102)

Yazarın bu bölümdeki son makalesi, “Türkçe Konuşan Anadolulu Ortodoksların Ulusal Bilinçlenme Sürecinde Karamanlıca Kitapların Önsözleri” adını taşımaktadır. Yazar burada ilk önce yukarıda bahsettiğimiz kimlik ve tanımlama soruna değiniyor. Başkalarının onları tanımlama girişimlerine karşın Karamanlıca yazılan veya bu dile çevrilen yazıların önsözlerinde yazarların / çevirmenlerin onlara nasıl hitap ettiklerini dönemsel olarak ele alıyor. Buna göre, ilk dönemlerden 1826'ya kadar hitap "Hristiyanlar" şeklindedir. 1826'da misyonerlik faaliyetlerini desteklemek için kurulan Kitab-1 Mukaddes Şirketi'nden (Bible Society) sonra hitap "Hristiyan Ortodokslar" ve "Anadolu Hristiyanları" 
şeklinde olur. Yazar göre bu kullanımlarda geçen "Hristiyan" ifadesi onları Müslümanlardan, "Ortodoks" ifadesi Protestan ve Katoliklerden, "Anadolu" ifadesi ise Yunanistan'da yaşayan Ortodokslardan ayırmak için kullanılmıştır. Dolayısıyla bu ayırımın etnik temelli değil, çoğunlukla dinsel aidiyeti vurgulamak için yapıldığını söyler. Okuyucuya doğrudan hitaplarda da ilk dönemlerde "dindaş" veya "kardeş Hristiyan" şeklinde seslenilirken, bunun 1864 sonrasında "vatandaşlar, Anadolulu Vatandaşlar, Ortodoks Vatandaşlar" şekline dönüştüğünü söyler. (s108-112) Yazar 19. ve 20.yüzyllarda etnik temelli anlayış üzerine kopan büyük fırtınalara rağmen bunların herhangi bir etnisiteye tabi olmaksızın, haklı olarak, neden hala kendilerini "Anadolulu Hristiyan Ortodokslar" şeklinde tanımladıklarının üzerinde durulması gerektiğine dikkat çeker. (110). Burada "vatan" kavramı kullanılarak yaşanılan yer, yani Anadolu ön plana çıkartılmıştır. Yazarın ifadesine göre bütün bu yazımların hemen hiç birisinde "Yunanistan" ve "Yunan (Ellinis/Helen) sözcüğü geçmemiştir. Yazar, Osmanlı Millet Sistemine göre nasıl ki diğerleri (Bulgar, Sırp vb bir döneme kadar) Rum Ortodoks Kilisesi'ne (Patrikhane) bağlı Rum Milletine tabi idiyseler, bunlarda kendilerini bu manada "Rum" olarak tanımliyorlardı, der. (112)

\section{Karamanlılar ve Karamanlıca Kitaplar}

Kitabın ikinci bölümü, "Karamanlılar ve Karamanlıca Kitaplar" başlı̆̆ını taşımakta ve toplam 6 makaleden oluşmaktadır. Bu bölümdeki ilk makalenin başlığı, "Gerçi Rum isek de Rumca Bilmez Türkçe söyleriz. Vatan, Din ve Dille Bölünmüş Bir Kimliğin Serüvenleri” şeklindedir. Makalenin ilk bölümlerinde yukarıda kısaca bahsettiğimiz etnik köken kavramına değinilir ve burada bu toplumun nasıl ilgi odağı olmaya başladığını tartışır. 18. Yüzyılın ortalarından itibaren kilisenin bu toplumu diğer dinlerin propagandasına (Müslüman, Protestan, Katolik) karşı korumak için onların Ortodokslularına vurgu yaparken, İstanbul'daki entel Rumların da "Rumluğuna" vurgu yaptıklarına, Atina'nın ise "Helen"liklerine vurgu yaptığını söyler. (127) Bu arada millet sisteminin artık ortak kalkmasıyla "milliyetçilik" fikrini en geç benimseyen Türklerin ise onların "Türklüğüne" vurgu yapmaya başladıklarını ifade eder ve bu konuda ilk yazan kişinin Şemsettin Sami olduğunu söyleyerek onun “...Nasıl her Müslüman Türk değilse, her Ortodoks Hristiyan da Rum değildir. Din, inanç esasına dayanır ancak etnik köken dilin kullanımına bağlıdı»" sözü üzerinden konuya dair tartışmaları özetler. Burada Papa Eftimi hareketini kısa bir bilgi olarak zikreder (122-123). Akabinde yukarıda da değindiğimiz gibi Yunanlıların Anadolu'ya çıktıklarında Patrikhanenin kralcılar karşısında açıça yayılmacı Venizelosçulara taraf olmasının, Patrikhanenin itibarını yıprattığını söylemekle yetinir. (124) Yazarın Karamanlıların etnik bileşenleri sorununun Osmanlı Tapu Tahrir Defterlerinin incelenmesiyle konunun "kesin açıklığa kavuşacağını" söylemesi, açıkçası yazarın itidalli duruşu karşısında bize çok iddialı bir söylem gibi geldi. (125). Yazar burada Karamanlıların İstanbullu Rumlar ve Atinalılar tarafından Rumca eğitimle "aydınlatılması" gereken cahiller olmakla itham edildiklerini, o dönem onlara biçilen rolün Rumca /Yunanca eğitimle bu kültürün alıcıları olmaları gerektiği inancıydı, der. (127).

Yazar, bundan sonra Karamanlıların aydınlatılması gereken "cahil” toplum olarak görüldükleri yıllarda bu kültürün yüzlerce basılı eseri olduğunu hatırlatarak bunlar hakkında bilgi verir. (129) Yazara göre Yunan harfleriyle basılı bilinen ilk Türkçe metin, Martin Crusius'un Turco-Graeciae adlı yapıtın içindeki Gennadios Sholarios'un İtirafları'dır. Burada biz bunun müstakil bir eser olmayıp bir başka eser içinde yer alan bir bölüm olduğunu anlıyoruz. Yazar, eğer bu eser esas alınırsa ilk Karamanlıca kitabın 1584'e kadar gidebileceğini, ancak müstakil bir eserin ise 1718'de basıldığı, bunun da 1729'da İstanbul'da Osmanlı Türkçesi’nde basılan ilk kitaptan daha önce olduğunu söyler. (s.165-166) Yukarıda bahsedilen Karamanlıca yayınlanan ilk kitap (1718) Arta Metropoliti Neofitos Mavromatis'in kaleme aldığı 
Apanthisma tis Hristianikis Pisteos (Hristiyan inancının müdafaası), Karamanlıca ismiyle Gülzâr-ı İmân-ı Mesihi (Hristiyan İnancı Güldestesi) adlı eserdir. Bu eser, kilise dilini (Rumca/Yunanca) bilmeyenlere, Ortodoks inancını anlatmak ve onları diğer din propagandalarına (Protestan, Katolik) karşı korumak için yazılmıştır. Dolayısıyla ilk dönem Karamanlıca eserlerin tamamına yakını dini kitaplar olup yazarları da rahip ve keşişlerdir. Karamanlıca'nın ikinci dönemi olarak tanımlanan 1826 sonrası devreye giren misyonerler, 1826-1920 arası birçok Karamanlıca eser basarak bunları bedelsiz dağıtmışlardır. Tüm Karamanlıca kitapların içinde bunların oranı \%29'dur. Yazar dipnotta bu yayınlara dair uzun bir kaynakça verir. (130-131). Ayrıca bu ikinci dönem Karamanlıca eserlerde artık din dışı eserler de yayınlanır. Fransızca'dan çeviri edebi eserler ve romanlar, başta Temaşa-i Dünya olmak üzere Köroğlu, Âşık Garip ve Şah İsmail gibi popüler kitaplar da yayınlanır, ayrıca Tanzimat sonrası hukuk mevzuatlarına dair de çevriler yapılır. Burada sadece Temaşa-i Dünya'nın yazarı Evangelios Misailidis'in Anatoli gazetesinin matbaasında basılan kitap sayısı 17'dir. Yine Misailidis, 92 adet yayınla, tüm Karamanlıca yayınların \% 3o'unu gerçekleştirmiş önemli bir isimdir. (132-134). Yazar Yunan tezine karşı makaleyi şu cümleyle bitirir : "Türkçe konuşan Ortodokslarm milli bilinci ve aynı soydan gelen halklarm bir devletin sinurlar içinde toplanması esasına dayanan irredentist ideolojiyi benimsemeleri, hiçbir zaman Nüfus Mübadelesi sonrasında yeniden yazllan Yunan tarih metinlerinde efsaneleştirildiği düzeyde olmamıştır." (140)

Bu bölümün ikinci makalesi "Karamanlılar, Karamanlıca ve Karamanlıca Kitap Üretimi” başlığını taşıyor. Makalede bazı tekrarlar var, farklı olarak bazı istatistiklere yer verir. Örneğin KAAM’ın yaptığı 1930-1950 arası yaptığı araştırmalara göre Kayseri, Nevşehir ve Niğde üçgenindeki 81 Rum yerleşim biriminden 32'sinde Rumca, 49'unda ise Türkçe konuşulduğunu söyler (141) Ancak bu istatistiğin ne tür verilerle elde edildiğinden bahsetmez. Yazar, bu bilginin dipnotunda başka bir Yunanlı kaynaktan aktardığına göre Karamanlıca'nın kullanımının Türklerin Anadolu'yu fethetmelerine kadar dayandığını, yerli Rumların bir kısmının (bu kaynak onların kökenlerinin Rum olduğu tezini destekliyor görünüyor) yeni Fatihlerin dilini zamanla benimsediklerini, hatta bazı duaların ve Durmuş, Aslan, Kıymet, Nazlı, Mayısgülü, Gülistan, Güllü gibi isimlerin benimsendiğini söyler.

Yazar makalenin ilerleyen bölümlerinde Alman tarihçi Fallmerayer’in, bugünkü Yunanlıların antik Yunanlılarla aynı soydan gelmedikleri tezine karşı yeni bir ulus inşa etme çabasındaki milliyetçi Yunanlıların şiddetle karşı çıktıklarını, dolayısıyla kendi tezlerini baltalayan Anadolulu Ortodoksların Yunanlılaştırılması projesine ağırlık vererek yaptıkları eğitim faaliyetlerinden bahseder. Bu arada olaya yeni kurulmakta olan Yunan devletinin nasıl baktığını yansıtan Dimitrios K. Vizantios'un 1836'da yayımlanan ve bu gün bile Yunan Edebiyatında hala önem atfedilen Babylonia adlı tiyatro eserini örnek verir. Piyeste Navarin'de müttefiklerin (Osmanlı'ya karşı) kazandığı zaferi kutlayan farklı dillerdeki aydınların konuşmalarına, bazı bölümlerde de Karamanlıların şivelerine yer verilmektedir. (146). Yazar genel olarak kendilerinin farklı olarak tanımlayan Karamanlıların karakteristik özelliklerinden bahsederken onların dışlanmışlıklarından dolayı içe kapanık organize bir cemaat içi örgütlenmeye sahip olduklarını, bulundukları büyük şehirlerde kurdukları derneklerle dayanışma içinde bulunduklarını, gurbette kazandıklarını memleketlerine göndererek burada eğitim, kültür faaliyetlerine destek olduklarını, hayırsever insanlar olduklarını söyler. (148)

Eserin ikinci bölümünün üçüncü makalesi "Karamanlıca Kitapların Konu ve Döneme Göre Tasnifi” başlı̆̆ını taşır. Makalenin başında yazar bir kaynağa atıfla Karamanlıların Yunanca konuşan Ortdokslar tarafından; yarım Hristiyan, Yunan adına layık olmayan, galiplerin (Türklerin) dilini konuşan, kara dinli olan Karamanlılardır, şeklinde ötekileştirildiğini ifade eder. (s.164) Bu girişten sonra yayınlarla ilgili istatistiklere yer verir. Buna göre bu gün Karamanlıca bibliyografya sayısı 752 kitabı içermektedir. 
(Bunların 124’ü müstakil olmayıp başka bir kitap içinde bölüm olarak yer alanlardan oluşur) Müstakil eserlerin 340'ı dini, 288'i ise din dışıdır. Bunlar içinde de misyonerlerin yayınladıkları 181 adettir (Tüm Karamanlıca kitapların \%29’u) Yazar Karamanlıca eserleri, ilk dönem 1751-1830 ve ikinci dönem 18311935 olarak ikiye ayırır. İlk dönemin çoğunluğunu dini kitaplar oluşturur. İkinci dönemde yayınlananlar ise dini kitaplar, din dışı kitaplar (sözlük, tıp, coğrafya, tarih, tarım, ansiklopedi), halka yönelik risaleler (Köroğlu, Şah İsmail, Âşık Garip vb), şiir ve tiyatro türünde kitaplardır. (s.165-188)

Bölümün üçüncü makale başlı̆̆ı, "Evangelinos Misailidis’in Yunanca ve Karamanlıca Yayınlarına Osmanlı Kaynaklarının Tanıklığı” şeklindedir. Yazar burada Karamanlıca bir kitabı değil de, kahramanı Karamanlı Hacıaslanis adlı bir tacir olan Sevdalı Hacıaslanis isimli tiyatro eserini tanıtır. Yazar burada bir takım örnekler vererek bu tiyatroda geçen bir çok argo kelimelerden dolayı ahlaka muğayir bulunarak yasaklandığını söylerken, aynı tarihlerde Karamanlıca yayınlanan Temaşa-i Dünya’nın da benzer ifadeler içermesine rağmen niçin yasaklanmadığını tartışır. Yazara göre muhtemelen asıl neden, Hacıaslanis'in piyesinde Yahudi tiplemeleri ve onların kutsalları üzerinden yapılan aşırı argo ve aşağılayıcı, bu günün ifadesiyle Antisemitik ifadelerin Osmanlı Milletleri içinde bir düşmanlığa neden olabileceği düşüncesidir. (s.194, 203-207).

Yazar, bir sonraki makalesi olan “Kolera Günlerinde (1848-1854) Karamanlıca Yayınları”nda bu salgın hastalığa dair bilgiler veren Karamanlıca yayınlardan bahseder. (211-225). Eserin ikinci bölümünün son makalesi, "Karamanlıca Yayınlar Üzerine Bibliyografik Notlar" adlı birkaç sayfalık çalışmadır (229-239) Burada Yunan ve Ermeni harfleriyle Türkçe olarak basılan bazı ders kitapları ve dini kitaplar hakkında, kapak resimleriyle birlikte kısa bilgiler verir. Bu arada yazarın bu çalışmasının bazı yerlerinde Karamanlılar gibi yazma ve konuşmada farklı dil ve alfabe kullanan Ermenilerden de bahseder. Dolayısıyla imparatorluğun bünyesinde Türkçe konuşan ve konuştuklarını Ermeni alfabesiyle yazan bir grup Ermeni de vardır. (s.235-239)

\section{Karamanlıca Süreli Yayınlar}

Kitabın üçüncü ve son bölümü, "Karamanlıca Süreli Yayınlar" adını taşımakta ve 6 makaleden oluşmaktadır. Genel itibariyle bu bölümlerde verilen bazı bilgiler tekrar mahiyetinde olduğu için makalelerden kısaca bahsedeceğiz. İlk makale "Karamanlıca Basın (İzmir 1845 - Atina 1927)” başlığıyla verilmiş. Yazar burada Karamanlıca basımın tartışmasız en önemli ismi Evangelinos Misailidis (Temaşa-i Dünya'nın da yazarı) ve yayın faaliyetlerinden bahseder. Misailidis'in çıkardığı ilk Karamanlıca gazete, 12 Ocak 1845'de çıan ve 1846'nın sonuna kadar devam eden Pelsarat'il Maşriki'dir. Yine kısa süreli bir kaç daha dergi ve gazete çıaran Misailidis’in şüphesiz en uzun soluklu eseri, Anatoli (1851 - 1923) adlı gazetedir. Başlangıçta hafta iki, sonra üç kez çıkan gazete, 1893’ten itibaren günlük olarak çıkmaya başlamıştır. Yazar bir Yunan kaynaktan yaptığı alıntıyla, Anatoli'nin yayına başlamasından bir asır sonra (1951) Yunanistan'da çıkan birçok gazeteden çok daha iyi olduğunu söyler. Gazete büyük kentlerde yaşayan Karamanlılar tarafından taşradaki hemşerilerine kadar ulaştırılmıştır. (249-252). Burada yazarın 1913 tarihli bir Yunan gazetesinin, Anatoli hakkında yaptığı yorumu, kanaatimizce Karamanlıca'nın akibeti hakkında acı bir gerçeğin ifadesi olarak okumak gerekir diye düşünüyoruz. Zira yunanlı yazar gazetenin başarısını tirajının düşmesiyle! açıklamakta ve şunları yazmaktadır:

Anatoli Gazetesinin yayımlandığı zamandan bu güne ...kayıtları incelendiğinde oğlun babanın aboneliğini sürdürmediği görülür. Bunun sebebi...ebeveynlerin çocuklarının öğrenim görmesine önem vermeleri ve böylece Yunan harfli Türkçe yayımlanan bu gazeteye daha fazla ihtiyaç duymamalarıdır. Bu, Anatoli gazetesi için bir șeref ve gurur meselesidir.(s.251) (Vurgular bize ait S.İ.) 
Yazar bu alıntıya yaptığı açıklamada 20. Yüzyılın ilk on yılında gazetenin aboneliğinin 6oo’ü geçmediğini söyleyerek bunu Anadolu'da Yunanca eğitimin yayılmasına ve artık genç Karamanlıca neslin çoğunun Rumca konuşmasına bağlamaktadır. (s.251) Yazarın kendisi doğrudan ifade etmese de eser hakkında verilen bilgilere ve gazete yöneticilerinin Patrikhane ile yaşadıkları sıkıntılara baktığımızda, bir dilin yok edilmeye mahkum edilmesi gibi bir büyük başarının! arkasında Patrikhane ile İstanbul ve Atinada'ki hellen ideolojiyi görmek hiç de zor olmayacaktır. Zira yazarın ileride bahsettiği gibi, Bulgar Kilisesi ile Patrikhanenin yaşadığı sorunlarda Anatoli gazetesi Patrikhaneye muhalif olduğu gerekçesiyle bir süre kapatılacaktır. Bulgarlar, Patrikhane'nin Rumca baskısına karşı direnip kendi kiliselerini kurdukları için (1872) belki kendi kimliklerini korumayı başardılar. Oysa daha zayıf olan Karamanlılar, buna direnemedikleri için kendi kimlik ve dillerini koruyamadılar. (Burada Papa Eftim'in de yarım asır sonra Bulgarların izinden giderek onlar gibi kendi kilisesini 'Türk Ortodoks Patrikhanesini' kurma girişimini de hatırlamakta yarar vardır.) Sonuçta, ileride bahsedileceği gibi, açık açık Karamanlıları Rumlaştırmak için Atina’nın desteğiyle (kısa ömürlü olsa da) çıan “İ Areti”nin (Fazilet) yayın amacını da göz önüne aldığımızda, Osmanlıda neredeyse bir şekilde üç asırdır var olan bir dilin, mübadele sonrası bir on yılda (1936) nasıl yok olduğunun cevabını kolaylaşmaktadır. Aslında makalede yazarın son cümlesi meseleyi özetlemektedir. Yazar göre, Karamanlıca basın İzmir'de doğmuş, İstanbul'da hayat bulmuş ve Atina'da yok olmuştur. (258)

Bu bölümdeki diğer makale “Karamanlı Basını Kataloğu”. Yazar burada Karamanlıca olarak yayınlanan 27 dergi ve gazeteden bahsetmekte, bir kısmıyla ilgili açıklayıcı bilgiler verirken bazılarını ise sadece isim olarak zikretmektedir. Makalenin sonunda ise bu yayınlar için talep edilen izinlere dair Osmanlı Arşiv belgelerine yer verilmiştir. Osmanlıca metinlerde Karamanlıca "Rum'i-l hurûf ve Türki'l-ibâre" şeklinde ifade edilmiştir. (s.259-276).

Eserdeki bir başka makale "Bulgar Sorununun Yaşandığı Dönem Mikra Asya yani Anatoli” adını taşımakta. Burada makaleye geçmeden evvel kısaca Bulgar sorununu hatırlamakta yarar vardır. Osmanlı Millet sistemi içerisinde aynı mezhebe bağlı Yunan, Bulgar, Sırp, Arnavut vb "Rum Milleti” adıyla anılmış ve dini konularda İstanbul Kilisesi’ne (Patrikhaneye) bağlanmışlardır. Ancak zamanla ulusal akımların güçlenmesiyle yukarıda saydığımız halklar siyasi bakımdan bağımsız olmaya başladıkça dini açıdan da Patrikhane'den ayrılarak kendi bağımsız kiliselerini kurmuşlardır. Bunlar içinde en sancılı Bulgarların ayrllı̆̆ olmuştur. Bulgarlar, Patrikhanenin Bulgar dili ve kültürünü yok sayan Helen eğilimleri karşısında direnmişler, Patrikhane de onların bağımsızlığını tanımamış, onları Filetizm (Irkçlık) yapmakla suçlamıştır. Fenerin bu direnci karşısında Osmanlı Sultanı 1870'de bağımsız Bulgar Kilisesi'nin (Eksarhlık) kurulmasına izin veren Fermanı yayınlamış, uzun süren müzakereler sonuç vermeyince Patrikhane Bulgarları 1872'de Aforoz ettiğini ilan etmiştir. İşte bu mücadele sirasında Anatoli gazetesinin sahibi ve yazarı Evangelinos Misailidis, dilsel ve etnik ayrımcılık yaptıkları ve bu süreci iyi yönetemedikleri gerekçesiyle hem Patrik VI. Grigoryos hem de halefi Patrik VI. Anthimos ve Patrikhane aleyhinde yazılar yazmıştır. Buna karşı Patrik de gazeteyi Türkçe yazdığı için "milli olmamakla" itham etmiş, gazetenin sahibi Misailidis'in Patrikhane toplantılarına katılmasını yasaklamıştır. Bu tartışmalar içinde Anatoli gazetesi 1873'de Patrikhanenin şikayeti üzerine kapatılmıştır. Patrik tarafından küfürbaz olmakla itham edilen Misailidis, kapatılan gazetesini (isim değişikliği altında) Mikra Asya yani Anatoli adıyla yeniden yayınlayarak eski yayın çizgisini sürdürmüş, yeni gazetenin ilk sayılarında Patrikhane hakkında daha mutedil bir dil kullanmaya çalışmıştır. (280306). Misailidis'in o dönemki Patrikhane hakkındaki detaylı görüşleri, yazarın makalesinin sonunda birkaç sayfalık alıntı ve yorumlarla birlikte verilmiştir. (302-305, 309-311) 
Yazar eserini iki dergiyle tamamlar. Bunlardan ilki Aktis (Işın) Dergisi diğeri de $\dot{I}$ Areti (Fazilet) dergisidir. Bir yıl gibi kısa süreli çıkan Aktis, resimli bir dergi olup patriklerin, diğer önemli kişilerin ve çeşitli dini kurumların fotoğraflarına yer vermiş, edebiyat, sanat, müzik, film haberleriyle Karamanlıların artık "cahil, kaba insanlar" olmadığını ifade etmek istemiştir. Ayrıca Karamanlılar için, başta Kudüs olmak üzere Hristiyanların kutsal mekânlarına gidip "Hacı" unvanını almak büyük bir saygınlık kazandırdığı için derginin sayfalarında sık sık hac turları ilanları yer almıştır. Dergi Bulgar karşıtı ve Yunan taraftarı görüşleriyle ön plana çıkmıştır. (s. 313-323) Eserin sonunda kısaca tanıtılan bir diğer dergi olan İ Areti (Fazilet) de ancak 6 ay yayımlanabilmiştir. Dergi tümüyle kendini Helenizme adamış, Atina'yı Milli bir merkez olarak görmüş ve oradan beslenmiş, tüm yayın politikasını bunun üzerine kurgulamış on beş günlük resimli bir yayındır. Nihai amacını da "okurlarını zamanla Türkçe kullanmaya gerek kalmayacak noktaya getirmek” olarak tanımlar. K.K. Kosmidis tarafından çıkarılan bu ideolojik dergide Yunan Edebiyatı ve dili, tıp, tarım, kilise ve kızların eğitimi gibi konulara yer verilmiştir. (s.325 - 339) Ayrıca yazar makalenin sonunda bu dergiye ait bir makaleler dizini yayınlamıştır. Bu dizinlerden birinde (sayı 11) Güney Trakya'da 1912'de meydana gelen büyük depremle ilgili başlatılan yardım kampanyasına yer vermiştir. Yine yazar Evangelia Balta, bu bölümde bazı yerlerde konuya açıklık getirmek adına kendi penceresinden İstanbullu Rumların "Megali İdea" fikrine bakışlarını, (328-330), "Milli Lisan” adıyla yaptıkları faaliyetleri (335-337) açıklar. Yine ekte eğitim ve dile dair bazı uzun alıntıları sayfalarına taşımışıır. (s. 341, 343-345, 358-363)

Kitabın Türkçeye çevrilmiş olması, Türk Akademik camiasında yapılacak benzer çalışmalar için önemli katkılar sağlayacaktır. Eser, ele almış olduğu konu itibariyle içerisinde, bu coğrafyanın ortak tarihine, kültürüne, edebiyatına, dini inanç ve değerlerine dair birçok hikâye barındırmakta ve bu konularla ilgili çeşitli disiplinlere bol malzeme sunmaktadır. 